\title{
Aggressive Behavior Supporter in Liga Indonesia
}

\author{
Iis Marwan* \\ Departement Physical Education and Sports Science, Siliwangi University, Tasikmalaya City, West Java \\ Province, Indonesia
}

*Corresponding Author: Iis Marwan, Departement Physical Education and Sports Science, Siliwangi University, Tasikmalaya City, West Java Province, Indonesia

\begin{abstract}
Aggressive behavior is a bad characters that aims to harm others. It can wreak to others or the individual itself. One of the factors that influence it of soccer supporters is the high level of fanaticism. Supporters are one form of social groups that are relatively irregular and occur because they want to see something. This crowd is almost the same as audiences but unplanned. The purpose of this study is to describe aggressive behavior of soccer supporters in liga Indonesia. This study uses a qualitative method. Informants from this study were chosen by purposive sampling with the characteristics of soccer supporters who live in Jakarta, Bandung and Malang. The results of this study show that 1) Aggressive behavior on the supporters arise because of the rivalry football club at the time of the game and the provocation between supporters 2) Aggressive behavior of verbal supporters who sing songs with ribaldry and racist, 3) Aggressive behavior encountered on supporters are physically provoked and then throw objects sych as plastic bottles at each other and damage facilities. Aggressive behavior in supporters arise because of the rivalry and mutual provocation between supporters, then arise aggressive behavior verbally and physically.
\end{abstract}

Keywords: Aggressive, Behavioral, Fanaticism, Soccer, Supporter.

Abbreviations: PERSABAYA: Persatuan Sepakbola Surabaya (Football Club From Surabaya), PERSIB: Persatuan Sepakbola Bandung (Football Club From Bandung), PERSIJA: Persatuan Sepakbola Jakarta (Football Club From Jakarta), PERSEMA: Persatuan Sepakbola Malang (Footbal Club From Malang), Jack Mania: Supporter name from persija, Viking: Supporter name from persib, Bonek: Supporter name from persibaya, Aremania: Supporter name from arema

\section{INTRODUCTION}

Football's traditions in Indonesia as well as in the world, soccer clubs have members of a group of supporters known as twelve players coming from the city or area from which the club originated. This resulted in a strong regional fanaticism in each supporter group that resulted in a vulnerable friction between supporters if the clubs meet each other.

Supporters become part of the club that play, fanaticism supporter is commonplace or commonplace in every football event either league or presidential trophy from year to year continue to increase. More and more football clubs more supporters. Where his club play is always followed by his supporters, tirelessly, far or how much money should be spent, the main club play and win.

However, the presence of supporters does not always cause comfort for other audiences, often making a commotion or a turmoil that has been done since leaving to the stadium or even until returning home to their respective areas.

In Indonesia all football clubs are always followed by the presence of supporters with a distinctive name, such as club PERSIJA supporters Jack Mania; PERSIB supporters Viking; PERSEBAYA suporternya Bonek Mania; and PERSEMA supporters Aremania, and many others.

Not a lot of matches took place there was a fuss between supporters, as happened at Manahan Stadium, Solo, Wednesday (09/04/2016), colored several beating incidents. High rivalry between two groups of supporters, indeed a trigger atmosphere is not conducive during the game. (Tribune News, 2016).

The data were taken through open questions to 100 respondents from three clubs that have many supporters (Jack Mania, Viking and Aremania) stated that the respondents were divided into three 
criteria according to how long a footballer supporter and aggressive behavior of the suporrter group. The first group of respondents began to become soccer supporters since junior high, high school because they want to support local football clubs in the area. A total of $62 \%$ of respondents stated that they are always present in football matches when the team they support play. Respondents declared racist singing as the club supported play that encouraged opposition from opposing supporters. Respondents stated that they would turn against each other if the opposing supporters attacked because of matches and songs containing taunts. Respondents resisted by throwing stones and bottles at opposing supporters, some respondents claimed to be involved in a brawl that ignited the emotions of both sides of the supporters' group. A total of $28 \%$ of respondents said participate sing songs, ignite fireworks and do not participate in resistance, respondents said they want to be safe and do not want to get involved with the brawl between supporters. They chose the path of peace by hiding in brawl. As many as $10 \%$ of respondents said they only participate in kempok supporters when singing and come in every supported team match. Respondents said they never took part in the fight but threw the bottle when there was a chaos going on in the field. From the above data it can be concluded that the respondent has a high aggressive level when the opposing supporter group attacks.

According to Yusoff (2015) in Malaysia, the issue related to the violence between football fans is not new. In fact, this problem has become more common in recent years. A series of interviews were conducted with several informants who were directly involved with football in Malaysia. The informants involved were the chairman of clubs supporting football Selangor, Perak, Johor and Kelantan. The four soccer teams are known to have a number of fanatical supporters, in addition teams are often fined by federations. Although various fines and penalties have been imposed primarily by The Football Association of Malaysia (FAM), this is still not sufficient to control supportive behavior. The law throws firecrackers, stone bottles, saur lamps, burning stadium seats, provocations, battles and disturbing public order between deviant and aggressive behavior perpetrated by some supporter supporters in Malaysia.

Based on some of the above description that aggression is influenced by provocation through sarcastic songs sung by supporters during the game so that opponent supporters provoked and aggression directly and indirectly.

This form of indirect active verbal aggression behavior often arises during the game. Almost all the games tend to sing songs that satirize the enemy even though not face-to-face, this is what encourages supporters to behave aggressively in soccer matches resulting in riots among football fans.

Based on the description above, researchers want to understand how aggressive behavior on football supporters. So the researchers took the title "Aggressive Behavior Footballers Supporters in Liga Indonesia".

\section{METHOD}

This research uses phenomenal approach because researchers want to get data in depth and more detail. Individuals in this study were taken by purposive sampling, ie the determination of individuals in accordance with predetermined criteria. Informants in this study used the supporters group Jack Mania, Viking and Aremania consists of men and women. One of the reasons why researchers choose a group of supporters as a research subject because of loyal supporters (obedience and / or loyalty), proof of their loyalty is always faithful to support his team when competing wherever and whenever. Informants in this study is soccer supporters, it is based on the initial data retrieval of 150 respondents.

Determination of informant researchers as many as 7 informants, the process of taking informants done with snow ball that is requesting a reference to previous informants or others to new informants in accordance with the criteria. Data collection using in-depth interview techniques and observation using interview guides based on aspects of aggressive behavior are: 1) self-defense, 2) superiority, 3) desire to attack 4) Egocentric (Schneiders, 2010), also 1) Krahe, 2005).

\section{DISCUSSION}

The purpose of this study was to find and describe aggressive behavior in soccer supporters. Overall aggressive behavior that emerged from all informants almost the same, but there are differences between informants. These differences can be seen from the age of the informant, sex, job. Aggressive 
behavior is seen from the age of each informant is different, the informant aged 16 to 19 years showed the form of aggressive behavior such as throwing stones and throwing firecracking this in accordance with the statement Berkowitz (2009) Aggression is a deliberate act of intentional acts by a person / institution against other people / institutions which is in fact deliberate. The 20 to 23 informants showed the same behavior, the informants tended to group, from the results of the informant's research 1, the informant 2, the informant 3 aged between 20 to 23 years and the informant 7 aged 25 years showed aggressive behavior in group time, Soekanto (2006) explains that supporters are a form of social group that is relatively irregular and occurs because they want to see something (spectator crowd).

This crowd is almost the same as the audience, but the difference in the crowd spectator is the unplanned crowd, and the activities are generally uncontrollable. Hornby (in Silwan, 2012) defines a supporter as someone who supports a group or a thought. Alwi (2005) defines supporters as those who provide support, encouragement, in matches. Alwi (2005) defines supporters as supportive, supportive, and supportive. Hornby (in Silwan, 2012) defines supporters as someone who volunteers to take part in supporting a theory, concept, and activities.

Aggressive behavior of informants who were shown at group times like singing dirty words, singing racist songs, throwing objects around them, carrying sharp weapons, carrying Molotov bombs and destroying stadium facilities. Aggressive behavior is a behavior that other people commit to harmful themselves and others. Behavior is everything we do that can be observed directly (King, 2012). Aggressive behavior can cause physical or emotional harm to others. It may range from verbal abuse. It can also involve harming personal property (Walid, Briki et all. 2013).

\section{ReSUlts}

Informants have different gender, 6 out of 7 informants are male and 1 female informant. Male informants are more likely to be aggressive at group time, this is in accordance with situational factors that affect aggressive behavior. Aggressive behavior is often based on conflict between groups. Intergroup conflicts are often triggered by in-group vs. out group feelings, so that group members are colored by prejudice (Krahe, 2005). From the results of the study stated that the informant group retaliated when the opponent group attacked first, the behaviors shown such as reply to the stone throw, throw flares.

This is different from the informants with female sex, the informants are sexually more passive and do not aggression. The female informant joined the group at the time of supporting the football club, but when the opposing supporters attacked the female informants did not participate in the attack and chose to take refuge, this was because at the time of the riot the male informant asked women informants to take refuge and was not allowed to participate.

Informants have different jobs, soccer supporters can generally be found on a variety of jobs, ranging from students, students, laborers, and street vendors.

Aggressive behavior that arises in individuals in various supporters' jobs when supporting football clubs, as Freud (2008) claims humans have an unconsciousness that leads to destructive behavior, called Thanatos / death instinct / ag gressive instinct. That is, aggressive behavior is an instinctive behavior, that is driven from within the individual.

According to Schneiders (2010) describes that aggressive behavior is formed from the defense of the tendency of the aspect to vent his desires and his uncomfortable feelings, such as those aimed at the informant when the opposing supporter comes with bad intentions will welcome the suporiarity of the informant who considers himself more in support of his football club. Supporters will show their fanatics when supporting their football clubs, as soccer clubs backed by informers began to show aggressive behavior such as damaging stadium facilities and lighting flares. Attempts to attack is shown by informants because they feel uncomfortable with the circumstances around, from the results of mutual mocking research in club defeat will trigger a riot, the behavior shown is throwing bottles, stones, wood and firecrackers towards the opponent. Assault is one of the most common causes of aggressive behavior and occurs in the form of verbal or physical attacks. The existence of attacks from other people will cause an aggression reaction from a person. According to Krahe (2005) aggressive behavior arises because of instigation, including aggressive behavior that occurs due to provoked or countermeasures. From the results of provocative research is often done informants at 
soccer games, the provocative form that is shown is to sing using dirty words, using racist songs, put banners with words of derision. From the research results of the egocentric aspect, the informants stated that they were more likely to be concerned with the group at the time of attack. The attitude of informants who tend to emphasize or prioritize personal interests without regard to the interests of others, informants said the group of supporters and football club is very important for him because it is a pride to support football club from the origin of informants.

\section{CONCLUSSiON}

From the above research results can be summarized are: 1) Aggressive behavior in supporters arise because of the rivalry football club at the time of the game, the emergence of aggressive behavior because supporters provoke each other by using the song with dirty words and racist. Based on the age of football supporters, the results of studies aged 17 years to 25 years more often show aggressive behavior. Based on sex, from the results of the study can be seen that the sex of men showed more aggressive behavior than female gender. Women are more likely to be passive, not showing aggression. 2) Aggressive behavior that verbal supporters spawn is singing dirty words, then physically throwing things around, throwing bottles, throwing flares, carrying sharp weapons, Molotov cocktails, and destroying stadium facilities. 3) Aggressive type of behavior generally found in football supporters is aggressive verbal behavior of singing songs with dirty words, singing racist songs and physically throwing objects at each other.

\section{ACKNOWLEDGEMENT}

Based on the results of the research and conclusions obtained during the study, the authors contribute suggestions that are expected to be useful: 1) For informants in order to minimize aggressive behavior that harms themselves and others by refraining from provoking. By sharpening the creativity of the field like singing positive and attractive yells that are shown to players and supporters of the opponent, then make choreography and celebration is not excessive. 2) For members of the supporters are expected to provide good examples such as raising funds to create supporter attributes in support and show how to support football well. 3) For further researchers who want to examine aggressive behavior on soccer supporters hope this research results into a useful reference.

\section{REFERENCES}

[1] Alwi. Kamus Besar Bahasa Indonesia, Edisi Ketiga, Cetakan Ketiga. Jakarta: Balai Pustaka. (2005).

[2] Ana Caronna Vimieiro. Football Supporter Cultures in Modern-day Brazil: Hypercommodification, networked collectivism and digital productivity. Pontical Catholic University of Minas Gerais, Brazil

[3] Ardianto, J. Perilaku Agresif Suporter Sepakbola Ditinjau Dari kecerdasan Emosional. Skripsi, Semarang: Universitas Katolik Soegijapranata. (2010).

[4] Dalpian, P.R.C., V.S Zylbersztejn, Zeno B., Carlos Alberto V.R. Fanatical Women and Soccer: An Exploratory Study, Soccer \& Society; DOI: 10.1080/14660970.2013.828598. (2013).

[5] Dimmock, A. James and J. Robert Grove. Relationship of Fan Identification to Determinants of Aggression. Journal of Applied Sport Psychology. (2007).

[6] Dongoran, Fadli. Agresi pada Suporter. Academi.edu. (2017).

[7] Dotson, M.J., Dana Clark J., Michelle B. Suber, Dinesh S. Dave. Millenials Perceptation of Spectator Sports. Service Marketing Quarterly, 34:3, 215 - 230. (2013)

[8] Frias, Francisco Javier Lopez. The Psycho-Biological Bases of Sports Supporters' Berhaviour: The Virtuous Supporter'. Sport, Ethics and Philosophy. (2012).

[9] King, L. A. Psikologi Umum. Jakarta: Salemba Humanika. (2012).

[10] Krahe, B. Buku Panduan Psikologi Sosial: Perilaku Agresif. Yogyakarta: PT Pustaka Belajar. (2005).

[11] Lucky, N. \& Nanik S. Fenomena Perilaku Fanatisme Suporter Sepak Bola (Studi Kasus Komunitas Suporter Persebaya Bonek di Surabaya). Kajian Moral dan Kewarganegaraan 2013, 1 (1). (2013).

[12] Putri, Dhella A. D. The Relationship Between Fanaticism of Club and Aggressive Behavior Tendencies Of Foreign Football Fans In Yogyakarta. Yogyakarta: Universitas Gadjah Mada. (2014).

[13] Sarwono, S. W. Psikologi Remaja. Jakarta: PT. Raja Grafindo Persada. (2008).

[14] Sarwono, S. W., \& Meinarno, E. A. Psikologi Sosial. Jakarta: Salemba Humanika. (2009).

[15] Silwan, Argubi. Aggressive Behavior Pattern, characteristic and Fanatiscm Panser Biru. Journal Of Physical Education And Sport Semarang Universitas Negeri Semarang. (2012).

[16] Shoham, Aviv and Vassilis Dalakas, Lia Lahav. Consumer Misbehavior: Aggressive Behavior by Sports 
Fans. Journal Servies Marketing Quarterly. Access in : http://doi.org/10.1080/15332969.2015.976506. (2015).

[17] Syarif, R. Perilaku Suporter Sepakbola. www.TribunNews.com/read/ 2013/10/08/ 0920254/. (2013).

[18] Walid, Briki et all. How do supporters positive and negative psychological momentum changes during a simulates cycling competition? Psychology of Sport and Exercise. (2013).

[19] Widijatmoko, K. Engelbertus. Meneropong Dinamika Tiga Dasawarsa Suporter Aremania. Universitas Kanjuruhan Malang. (2017).

[20] Yusoff, N. H. Relationship Between situational Factors and Deviant Behaviour Among Footbal Spectators in malaysia. International Journal of Arts and Commerce, Volume 4 No 1. (2015).

[21] Yusoff, N. H. Types of Deviant Behavior among Football Fans in Malaysia . Mediterranean Journal of Social Science MCSER Publishing, Rome-Italy, Volume 7 no 1. (2016).

Citation: Iis Marwan. "Aggressive Behavior Supporter in Liga Indonesia" International Journal of Sports and Physical Education (IJSPE), vol 4, no. 1, 2018, pp. 14-18. doi:http://dx.doi.org/10.20431/24546380.0401004.

Copyright: (C) 2018 Authors. This is an open-access article distributed under the terms of the Creative Commons Attribution License, which permits unrestricted use, distribution, and reproduction in any medium, provided the original author and source are credited. 